\title{
Prevalence of bovine fascioliasis, areas at risk and ensuing losses in the state of Goiás, Brazil
}

\author{
Prevalência de fasciolose bovina, áreas de risco e perdas subsequentes no estado de Goiás, Brasil \\ Fernanda Martins de Aquino ${ }^{1}$; Vando Edésio Soares ${ }^{2}$; Gabriel Augusto Marques Rossi ${ }^{3}$; João Eduardo Nicaretta ${ }^{1}$; \\ Thiago de Souza Azeredo Bastos ${ }^{1}$; Leonardo Bueno Cruvinel ${ }^{1}$; Luiz Fellipe Monteiro Couto ${ }^{1}$; \\ Alliny Souza de Assis Cavalcante ${ }^{1}$; Gustavo Felippelli³; Breno Cayeiro Cruz ${ }^{3}$; Willian Giquelim Maciel’3; \\ Lucas Vinicius Costa Gomes ${ }^{3}$; Welber Daniel Zanetti Lopes ${ }^{1,4 *}$
}

\author{
${ }^{1}$ Escola de Veterinária e Zootecnia - EVZ, Universidade Federal de Goiás - UFG, Campus Samambaia, Goiânia, GO, Brasil \\ ${ }^{2}$ Universidade Brasil, Campus de Descalvado, Descalvado, SP, Brasil \\ ${ }^{3}$ Faculdade de Ciências Agrárias e Veterinárias - FCAV, Universidade Estadual Paulista - UNESP, Jaboticabal, SP, Brasil \\ ${ }^{4}$ Instituto de Patologia Tropical e Saúde Pública - IPTSP, Universidade Federal de Goiás - UFG, Goiânia, GO, Brasil
}

Received July 26, 2017

Accepted March 5, 2018

\begin{abstract}
The present study had to determine the prevalence and spatial distribution of areas at risk of bovine fascioliasis in the state of Goiás, central-western Brazil between 2007 and 2014; to evaluate the associations of some epidemiological variables with occurrences of Fasciola hepatica in animals; and to estimate the economic losses that this parasite on the cattle industry. It could be concluded that of 23,255,979 animals slaughtered, the average prevalence of $F$. hepatica in cattle in Goiás during the period evaluated was $0.0026 \%$ (95\% CI: 0.0024-0.0028). In the State of Goias, in about then years (since when this parasite was found for the first time by other researchers in 2007), F. hepatica was diagnosed in 168 new municipalities. Using the regression analysis, the effective bovine herd size was a significant risk factor $(\mathrm{OR}=1.21 ; 95 \%$ CI 1.1022-1.4510; $\mathrm{p} \leq 0.05$ ) for cattle to be infected with fascioliasis in the state of Goiás. The cattle-rearing industry lost approximately R \$ 15,072.75 (US\$ 4,785) due to condemn of livers with Fasciola in the state of Goiás. New studies need to be conducted in these regions, with the aim to identify the likelihood of presence of intermediate hosts, which might serve as a source of $F$. hepatica infection for definitive hosts.
\end{abstract}

Keywords: Cattle, Fasciola hepatica, maps, spatial distribution, epidemiology, zoonosis.

\section{Resumo}

O presente estudo objetivou determinar a prevalência e a distribuição espacial das áreas em risco para fasciolose bovina no Estado de Goiás, regiáo Centro-Oeste do Brasil, entre 2007 a 2014; avaliando as associaçôes de variáveis epidemiológicas com ocorrências da Fasciola hepatica em animais; e estimar as perdas econômicas deste parasito em bovinos. Pode-se concluir que de 23.255 .979 bovinos abatidos, a prevalência média de $F$. hepatica durante o período avaliado foi de 0,0026\% (IC 95\%: 0,0024-0,0028). No Estado de Goiás, em aproximadamente 10 anos (desde quando esse parasito foi encontrado pela primeira vez por outros pesquisadores em 2007), F. hepatica foi diagnosticada em 168 novos municípios. Utilizando-se a análise de regressão logística, o tamanho do rebanho apresentou-se como um fator de risco significativo $(\mathrm{OR}=1,21$; IC 95\% 1,1022-1,4510; $\leq \leq 0,05)$ para os bovinos se infectarem por $F$. hepatica no referido Estado. O prejuízo, devido à condenação de fígados com Fasciola nos bovinos no Estado de Goiás, foi de R 15.072,75 (US 4.785). Novos estudos precisam ser conduzidos nessas regióes, com o objetivo de identificar a presença de hospedeiros intermediários infectados, que podem servir como fonte de infecção por $F$. hepatica para hospedeiros definitivos.

Palavras-chave: Bovinos, Fasciola hepatica, mapas, distribuição espacial, epidemiologia, zoonoses.

\footnotetext{
*Corresponding author: Welber Daniel Zanetti Lopes. Instituto de Patologia Tropical e Saúde Pública - IPTSP, Universidade Federal de Goiás - UFG, Rua 235, s/n, Setor Leste Universitário, CEP 74605-050, Goiânia, GO, Brasil.

e-mail: wdzlopes@hotmail.com
} 


\section{Introduction}

Fasciola hepatica is a parasite with an indirect life cycle, and its intermediate hosts are mollusks in the genus Lymnaea, among which Lymnaea columella, L. cubensis and L. viatrix are the main species in Brazil. This trematode causes fascioliasis, a disease that affects the liver and bile ducts of the definitive hosts of this parasite, which may be mammals, including humans (BENNEMA et al., 2014).

In the cattle industry worldwide, the losses due to fascioliasis have been estimated as approximately U\$ 3.2 billion per year, relating to factors such as decreased milk production and quality, weight loss, mortality of animals and condemnation of livers and carcasses in slaughterhouses, when these present concomitant cachexia (YOKANANTH et al., 2005). In Brazil, this parasite has been diagnosed in cattle at slaughterhouses in Rio Grande do Sul, Santa Catarina and Paraná (southern region), São Paulo, Minas Gerais, Rio de Janeiro and Espírito Santo (southeastern region), Mato Grosso do Sul, Mato Grosso and Goiás (central-western region) and Tocantins and Pará (northern region) (ALEIXO et al., 2015).

Georeferencing is a tool that has been used for diagnosing parasitic diseases such as cysticercosis and fascioliasis, among others. The aim in using this technology is to determine the scale and spatial distribution of a specific agent, so that sanitary measures can then be taken, in an attempt to minimize the losses and harm caused by agents of viral, bacterial or parasitic origin (FERREIRA et al., 2014; BENNEMA et al., 2014; ALEIXO et al., 2015; ROSSI et al., 2016).

The frequency of bovine fascioliasis in the state of Goiás, central-western region of Brazil, is only barely known, given the sparsity and sporadic nature of the data available and the non-comparability of epidemiological variables. Therefore, the aim of the present study was to determine the prevalence, spatial distribution and areas at risk of this disease among cattle in Goiás. In addition, this investigation also evaluated the associations of some epidemiological variables with occurrences of $F$. hepatica in animals, and estimated the losses that this parasite causes in slaughterhouses, due to condemnation of affected livers.

\section{Material and Methods}

A retrospective study on the prevalence of bovine fascioliasis was conducted, using information from databases of the Brazilian Ministry of Agriculture, Livestock and Supply (Ministério da Agricultura, Pecuária e Abastecimento, MAPA), which are compiled by the Federal Inspection Service (Serviço de Inspeção Federal, SIF) in relation to slaughterhouses registered in Goiás. All animals, originated from 246 municipalities in this state, sent to these establishments were evaluated.

The animals were slaughtered in accordance with the standard meat production technology for cattle that is used in Brazil, and the carcasses were inspected in conformity with the current laws. These inspections include making incisions to view the bile ducts, and palpation and observation of the external surface of livers (BRASIL, 1952). In cases in which F. hepatica was detected, the livers were condemned.

Occurrences were grouped according to year (2007 to 2014), mesoregion (Figure 1A) and microregion (Figure 1B). The mesoregions (Center, East, North, Northwestand South) and microregions (Anápolis, Anicuns, Aragarças, Cataláo, Ceres, Chapada dos Veadeiros, surroundings of the Federal District, Goiânia, Iporá, Meia Ponte, Pires do Rio, Porangatu, Quirinópolis, Rio Vermelho, São Miguel do Araguaia, southwestern Goiás, Vale do Rio dos Bois and Vão

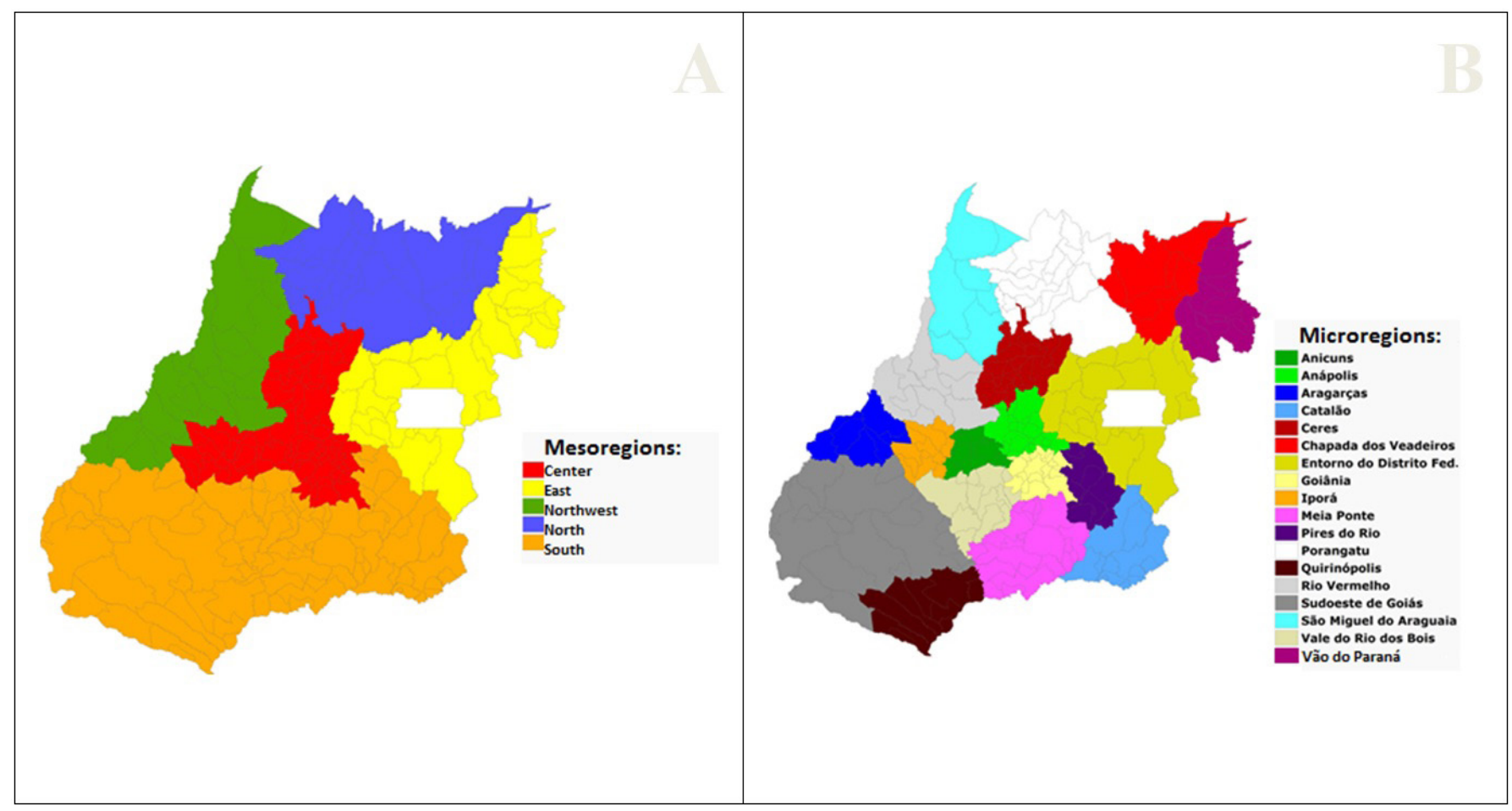

Figure 1. Spatial representation of mesoregions (A) and microregions (B) of the state of Goiás, Center-West region of Brazil. 
do Paranã) followed divisions established by the Brazilian Institute for Geography and Statistics (IBGE, 2016).

Statistical data from municipalities in the state of Goiás, such as effective herd size, population density, human development index (HDI), incidence of poverty (\%) and area of planted rice, were obtained from the IBGE website. Regarding the data of rural homes with semi-adequate sanitation systems, homes with sewage disposal into a septic tank, homes with sewage discharge into rivers or lakes and municipalities with fully treated water (yes or no), they were obtained from the IBGE website too, and these variables were analyzed because these epidemiological variables could indicate whether humans infected with $F$. hepatica might be influencing the spread of fasciolosis to snails and consequently cattle, and for this reason they were also evaluated .

\section{Data Analysis}

Regarding statistical analysis, data covering the period from 2007 to 2014 on the total occurrence of. F. hepatica observed in livers from cattle that had been slaughtered at locations overseen by the federal inspection service were used for prevalence calculations with $95 \%$ confidence intervals, for municipalities, mesoregions and microregions of the state of Goiás. The prevalence percentages were then ranked in increasing order for the municipalities, mesoregions and microregions. In this, the lowest prevalence observed was assigned an odds ratio (OR) of one, and the remaining ORs were calculated relative to this, using the $Z$ test to verify significance ( $p \leq 0.05)$.

Regression analysis was conducted. Initially, associations between prevalence (dichotomized using the median, with zero for values below this and one for values above it) and all epidemiological variables were been analyzed. These variables were the following: effective cattle herd size, population density, human development index (HDI), incidence of poverty (\%), area of planted rice, rural homes with semi-adequate sanitation systems, homes with sewage disposal into aseptic tank, homes with sewage discharge into rivers or lakes and municipalities with fully treated water (yes or no). From these data, simple binary logistic regression analysis was applied to all these variables, and the ones that presented $\mathrm{p} \leq 0.20$ were selected.

Following this, using only the variables that were significant in univariate analysis ( $\mathrm{p} \leq 0.20)$, multiple binary logistic regression analysis was performed. The strength of association between dependent and independent variables was estimated using odds ratios derived from logistic regression estimates. Here, only those that presented $\mathrm{p} \leq 0.05$ were considered significant.

All procedures manipulating these data were performed using the Epi Infosoftware, version 7.1.5.2 (CDC, 2015).

\section{Results}

Between 2007 and 2014, 23,255,979 bovine carcasses were inspected in the state of Goiás. Among these, 609 were diagnosed as positive for bovine fascioliasis, thus establishing a prevalence of 0.0026\% (95\% CI 0.0024-0.0028). The highest concentrations of animals positive for $F$. hepatica were observed in the central, northwestern and southern mesoregions of the state, according to the spatial distribution demonstrated in Figure 2A.

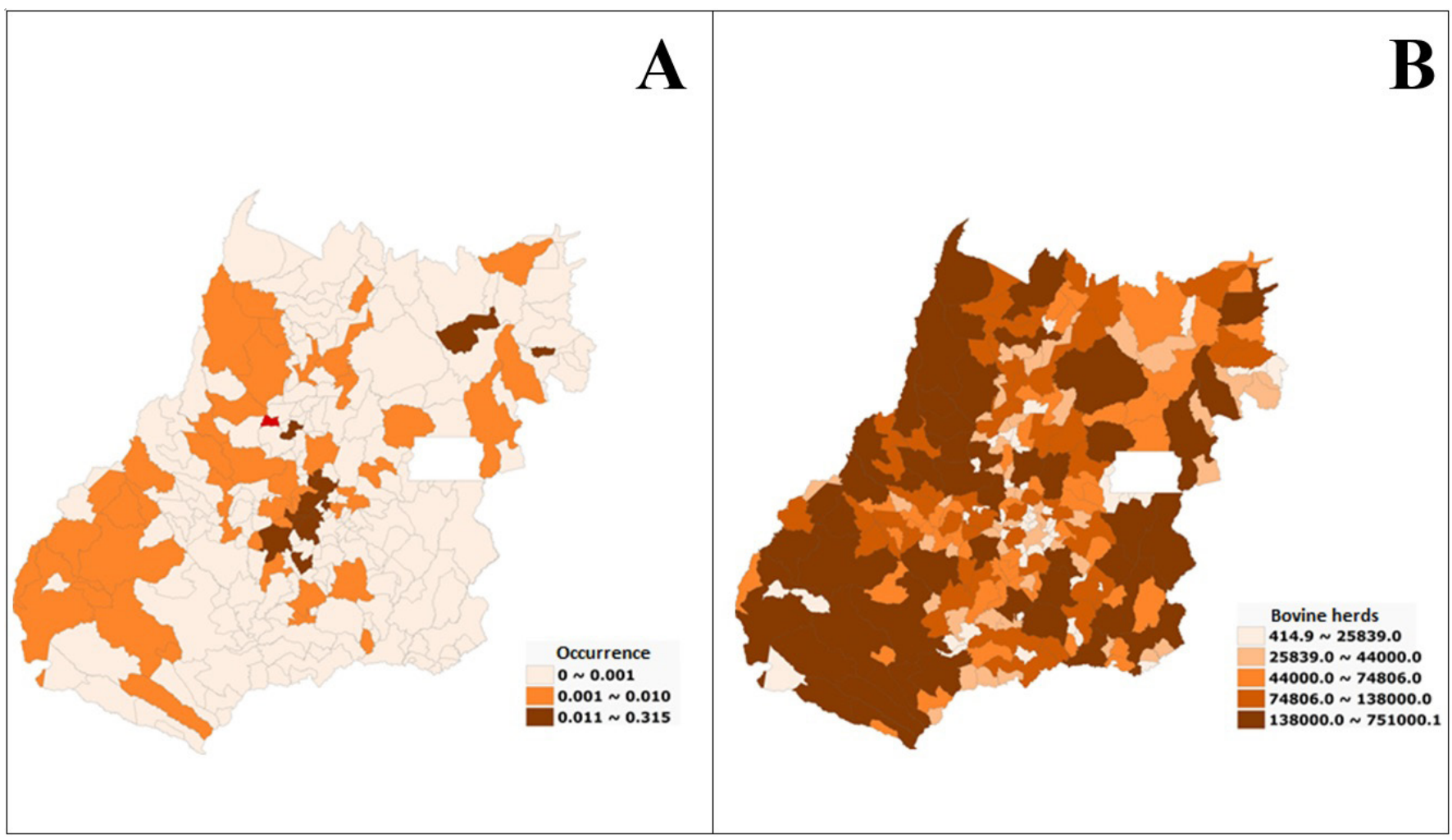

Figure 2. Spatial distribution of occurrence of bovine fascioliasis (A) and spatial distribution of effective bovine herds (B) on the state of Goiás, Center-West region of Brazil. 
Regarding the mesoregions evaluated, the one with the highest rate in the state of Goiás over the period selected was the central region, while the northern region presented the lowest prevalence (Table 1). Moreover, it could be seen that the central region and northwestern region were the ones presenting the highest chances of having cattle infected with $F$. hepatica (Table 1).

The microregions of Goiânia, Anápolis, Aragarças, Vale do Rio dos Bois, Chapada dos Veadeiros, Ceres, Anicuns, Southwestern Goiás, São Miguel do Araguaia, Surroundings of the Federal District, Vão do Paranã and Iporá presented higher risk $(\mathrm{P} \leq 0.05)$ of occurrence of fascioliasis, in comparison with the microregions of Meia Ponte, Rio Vermelho, Quirinópolis and Porangatu. In the microregions of Catalão and Pires do Rio, there were no reports of this disease, as can be seen in Table 2 .

In analyzing the results over the study period, it could be seen that among the 246 municipalities of the state, no animals positive for fascioliasis were identified in 177 . In the municipality of Anhanguera, there was no record of any cattle slaughtering.

The variables of population density, human development index, incidence of poverty, area of planted rice, rural homes with semi-adequate sanitation systems, homes with sewage disposal into aseptic tank, homes with sewage discharge into rivers or lakes and municipalities with fully treated water did not present any significant associations ( $p>0.05$ ) with occurrences of bovine fascioliasis, according to logistic regression analysis. On the other hand, using this same kind of statistical analysis, the effective bovine herd size was a significant risk factor $(\mathrm{OR}=1.21 ; 95 \% \mathrm{CI}$ $1.1022-1.4510 ; \mathrm{p} \leq 0.05)$ relating to the possibility that these animals in the state of Goiás would be infected with fascioliasis, such that the larger the herd in a mesoregion was, the higher the chances of finding cattle parasitized by F. hepatica would be (Table 3 and Figure 2B).

It is essential to emphasize the importance of the prevalence rates observed, regarding the economic aspects of this disease in slaughterhouses, which leads to condemnation of livers. Using the number of cases observed between the years 2007 and 2014 (609) a simulation on the financial losses caused to the meat industry through condemnation of these viscera was produced. For this simulation, the average weight of the livers was considered five kilograms, and the selling price of each kilogram was taken to be R $\$ 4.95$ or US\$ 1.57 (this amount was obtained from the Department of Finance of the state of Goiás), as detailed in Table 4. These amounts were then converted to United States dollars at the exchange rate of US\$1.00 = R \$3.15. Table 4 shows that in the state of Goiás, between 2007 and 2014, bovine fascioliasis gave rise to economic losses of nearly R $\$ 15,072.75$ (US\$ 4,785.00) to slaughterhouses, due to condemnation of livers that were diagnosed as positive for this disease.

\section{Discussion}

The prevalence rate observed in the present study $(0.0026 \%$; $95 \%$ CI $0.0024-0.0028$ ) was less than the rate of $0.03 \%$ that was described by Bennema et al. (2014) for the state of Goiás, but similar to rates in the remaining states of the central-western region of Brazil (Mato Grosso do Sul and Mato Grosso), which were $0.002 \%$ and $0.003 \%$, respectively. A possible justify for the difference found between the prevalence obtained by Bennema et al. (2014) is the sample size of cattle evaluated. In the work of these researchers, 1.9 million cattle were evaluated, while in the present study in Goiás and also in the studies carried out in Mato Grosso do Sul (PEREIRA et al., 2017) and Mato Grosso (ROSSI et al., 2016), approximately 23, 6 and 7 million animals were analyzed, respectively. These rates are considerably lower than those found in the state of Rio Grande do Sul, in the southern region of Brazil, where prevalence rates of $14.39 \%$ to $17.04 \%$ have been described (BENNEMA et al., 2014), and in the state of Espírito Santo, in the southeastern region, with a prevalence rate of $19.01 \%$ (MARTINS et al., 2014).

As observed on the present study, the chances of presence of cattle infected by $F$. hepatica (OR and $95 \% \mathrm{CI}>1$ ) were highest in the northwestern and central mesoregions. Moreover, the effective herd size also influenced the chances that animals might acquire fascioliasis. In the state of Goiás, fasciolosis was more commonly diagnosed where there was a higher concentration of cattle. As this animal species is also the definitive host of $F$. hepatica, with the presence of mollusks (intermediate host), the transmission of this parasite among cattle can be more easily when they are kept in a higher population density, which may justify the results found in this study.

Concerning the northwestern mesoregion, this is the area of lowest altitude in the entire state of Goiás, and it presents a rugged landscape. Among the 23 municipalities that form this mesoregion, 22 are part of the Araguaia hydrographic basin. This river serves as the border between the states of Mato Grosso and Goiás. Several pasture areas in these 23 municipalities suffer floods in the rainy seasons (October to March), due to the rise of the Araguaia river level. The volume of this river diminishes significantly in the dry season (April to September). Moreover, there are several small rivers belonging to the Araguaia basin in this mesoregion, which favors development of floodplain areas (SUESS \& CARVALHO, 2014).

The floodplains become flooded in the rainy season because of flash flood waters after rain on areas of higher ground. These bodies of water carry large amounts of feces, and possibly snails, onto the floodplains (Figure 3). The floodplain pasture areas remain greener during the dry season than do areas of higher grounds, which leads farm owners to take their animals to these spots, and which possibly helps to spread fascioliasis in these regions. The results found by Oliveira (2008) in Minas Gerais and Martins et al. (2012) in Espirito Santo reinforce this hypothesis. In Minas Gerais State, Oliveira (2008) observed an association between bovine fasciolosis and the presence of floodplains on farms in the municipalities of Itajubá and Careaçu, where $89 \%$ of the positive farms had floodplains. This association is considered relevant because floodplains are essential for the survival of the intermediate host, and thus, this association is considered to be a risk factor for the spread of fasciolosis. Already Martins et al. (2012) verified that the municipalities of Espirito Santo that presented low-risk areas for fasciolosis occurrence, were those that the highland exceeds $400 \mathrm{~m}$, which makes it unfavorable for the presence of flooded areas and thus for completion of the life cycle of F. hepatica. 


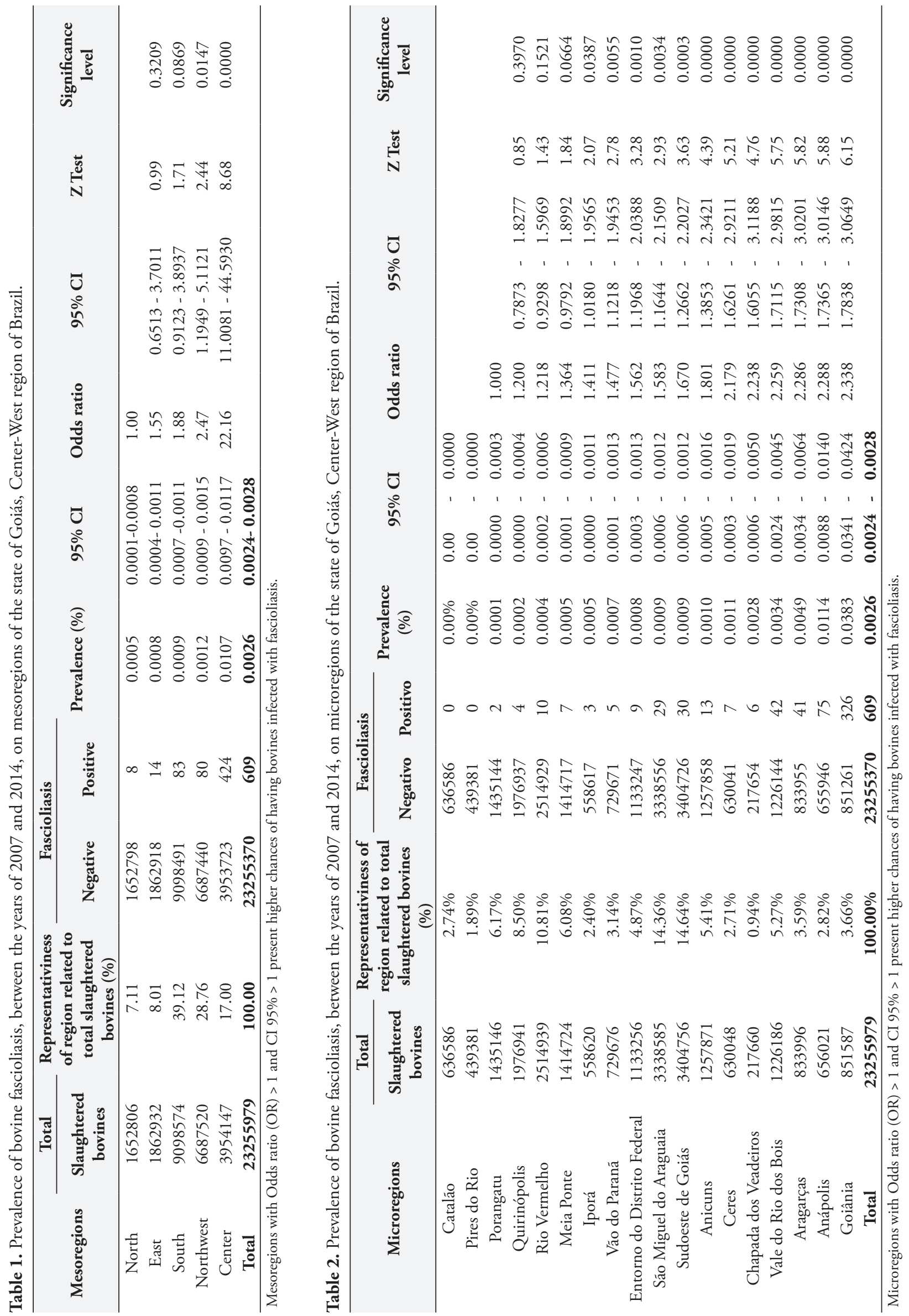


Table 3. Association between prevalence of fascioliasis, on the years of 2007 to 2014, with epidemiological variables using logistic regression analysis, in 246 municipalities of the state of Goías, Center-West region of Brazil.

\begin{tabular}{|c|c|c|c|c|c|c|c|c|}
\hline Variables & Odds Ratio & & $95 \%$ & & Coefficient & S.E. & Z-Statistic & P-Value \\
\hline Effective bovine herd & 1.21 & 1.1022 & to & 1.451 & 0.1910 & 0.000 & 3.848 & 0.0000 \\
\hline Population density & 0.99 & 0.9972 & to & 1.0022 & -0.0100 & 0.002 & -0.129 & 0.8108 \\
\hline Human development index (HDI) & 0.99 & 0.9817 & to & 1.0048 & -0.0100 & 0.005 & -0.388 & 0.2516 \\
\hline Incidence of poverty $(\%)$ & 1.01 & 0.9852 & to & 1.0556 & 0.0130 & 0.016 & 0.809 & 0.2646 \\
\hline Area of planted rice & 1.00 & 0.9997 & to & 1.0014 & 0.0000 & 0.000 & 0.923 & 0.1857 \\
\hline Rural residences with semi-adequate sanitation & 0.99 & 0.9949 & to & 1.0036 & -0.0100 & 0.008 & 1384 & 0.738 \\
\hline Residences with sanitary sewage (septic tank) & 1.00 & 0.9849 & to & 1.0191 & 0.0000 & 0.000 & -0.15 & 0.8326 \\
\hline Residences with sanitary sewage (rivers. lakes) & 1.00 & 0.9683 & to & 1.0367 & 0.0000 & 0.000 & 0.012 & 0.9122 \\
\hline Municipalities with fully treated water & 2.34 & 0.2716 & to & 20.2812 & 0.8500 & 1.063 & 1140 & 0.4381 \\
\hline Convergence: & Converged & & & & & & & \\
\hline Iterations: & 5 & & & & & & & \\
\hline Final $-2 *$ Log-Likelihood: & 260.21 & & & & & & & \\
\hline Cases Included: & 245 & & & & & & & \\
\hline Test & Statistic & D.F. & & P-Value & & & & \\
\hline Score & 28.90 & 9 & & 0.0007 & & & & \\
\hline Likelihood Ratio & 29.20 & 9 & & 0.0006 & & & & \\
\hline
\end{tabular}

Table 4. Simulation of economic losses caused to meat industry on the state of Goiás due to occurrence of fascioliasis in bovine herds, between the years of 2007 and 2014.

\begin{tabular}{|c|c|c|c|c|}
\hline Year & $\begin{array}{c}\text { Number } \\
\text { of cases }\end{array}$ & $\begin{array}{c}\text { Total } \\
\text { weight* }^{*}\end{array}$ & $\begin{array}{c}\text { Value of } \\
\mathbf{K g}^{* *}\end{array}$ & Total value \\
\hline 2007 & 191 & $955 \mathrm{Kg}$ & $\mathrm{R} \$ 4.95$ & $\mathrm{R} \$ 4,727.25$ \\
\hline 2008 & 2 & $10 \mathrm{Kg}$ & $\mathrm{R} \$ 4.95$ & $\mathrm{R} \$ 49.50$ \\
\hline 2009 & 69 & $345 \mathrm{Kg}$ & $\mathrm{R} \$ 4.95$ & $\mathrm{R} \$ 1,707.75$ \\
\hline 2010 & 21 & $105 \mathrm{Kg}$ & $\mathrm{R} \$ 4.95$ & $\mathrm{R} \$ 519.75$ \\
\hline 2011 & 159 & $795 \mathrm{Kg}$ & R\$ 4.95 & $\mathrm{R} \$ 3,935.25$ \\
\hline 2012 & 19 & $95 \mathrm{Kg}$ & $\mathrm{R} \$ 4.95$ & $\mathrm{R} \$ 470.25$ \\
\hline 2013 & 41 & $205 \mathrm{Kg}$ & $\mathrm{R} \$ 4.95$ & $\mathrm{R} \$ 1,014.75$ \\
\hline 2014 & 107 & $535 \mathrm{Kg}$ & $\mathrm{R} \$ 4.95$ & $\mathrm{R} \$ 2,648.25$ \\
\hline Total & 609 & $3,045 \mathrm{Kg}$ & - & $\mathrm{R} \$ 15,072.75$ \\
\hline
\end{tabular}

*Weight estimated as five kilograms; **Minimum value established by the Secretary of Finance from the State of Goiás.

The southern region, central region and two municipalities in the eastern region (Formosa and Flores de Goiás) were responsible for nearly $87 \%$ of all cattle confinements in the state of Goiás, as registered in the Goiás Agency for Agricultural Protection (Agência Goiana de Defesa Agropecuária, Agrodefesa). In this case, there is a possibility of transit of animals infected by fascioliasis, originating from areas where this disease is more frequent, such as the northwestern mesoregion (which accounts for only $2.7 \%$ of the state's confinements), and directed towards the other locations. Besides, since confinements increase the animal/area stocking rate, this system can constitute a risk factor for higher prevalence rates of fascioliasis in a specific mesoregion, according to previous reports (OLIVEIRA, 2008). This researcher verified in his study that a risk factor for cattle to acquire fasciolosis is when these are kept in an area that contains more than 10 animals/hectare.

Nevertheless, the results obtained from the present study reinforce the importance of conducting new investigations in the northwestern, southern and central mesoregions and in some municipalities in the eastern region, focusing on trying to identify possible mollusks that might be sources of infection with F. hepatica, definitive hosts in these regions.

Araújo et al. (2007) analyzed municipalities in the state of Goiás, in which the first reports of $F$. hepatica in the state were registered between 2002 and 2005, being that this same group of researchers, had already reported the presence of Lymnaea columella in the municipalities of Goiânia in 1995 (ARAÚJO et al., 1995). They detected this parasite in nine municipalities of this state located in the mesorregions Center (Goianira, Petrolina, Inhumas and Trindade), South (Indiara, Mineiros, Palmeira de Goiás and Palminópolis) and Northwest (Itapirapuã). In the present study, besides those nine places mentioned above, was possible to indentify F. hepatica in 168 new municipalities, located in all mesorrergions (Center, South, East and Northwest) of the Goiás state. These results show that in ten years there has been a considerable increase in the incidence of positive cattle in new municipalities/mesoregions of this State, which is of even more concern to both farmers and humans since this disease is a zoonosis.

Even though the association between bovine fascioliasis and the area of planted rice was not significant in the present study $(\mathrm{p}=0.1857)$, it is widely known that the association with these flooded areas is very important in some regions, since these locations are favorable for development and continuing presence of mollusks. Oliveira (2008), Alves (2010) and Martins et al. (2014) reported that there was an association between grazing in flooded areas and farms with animals infected by $F$. hepatica. Both Oliveira (2008) and Martins et al. (2014) also made correlations between presence of mollusks on the farm, sharing of grazing areas between cattle and other hosts, and the fact that animals drank water from a still source, such as ditches or reservoirs, as risk factors for occurrence of fascioliasis in the locations that they evaluated. On the other hand, Freitas et al. (2014) concluded that favorable climatic conditions alone (altitude, temperature, declivity and rainfall) 


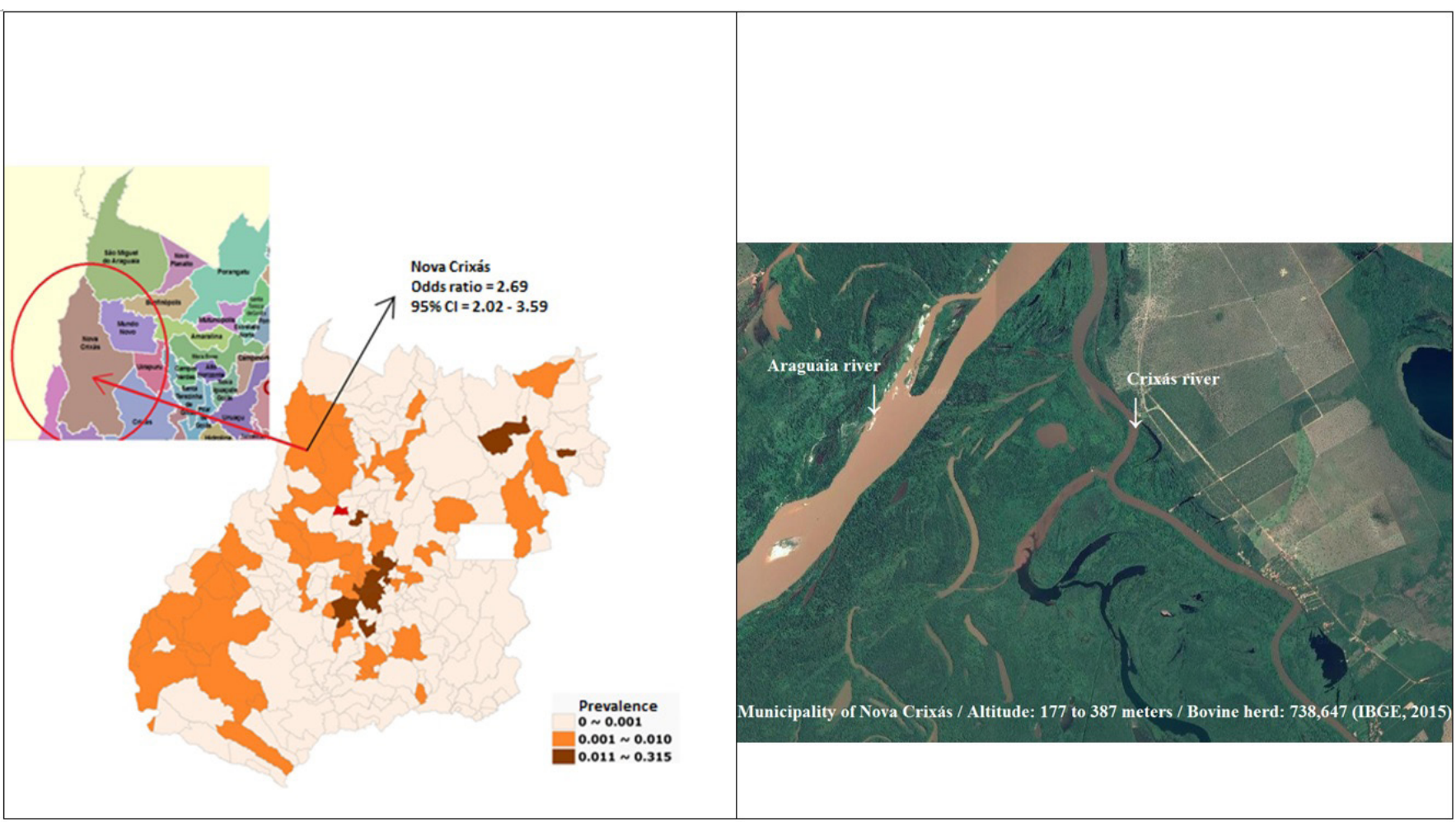

Figure 3. Municipality of Nova Crixás, state of Goiás (prevalence for bovine fascioliasis: $0.0012 \%$ ), presenting real images of floodplains (Google, 2017).

were not sufficient for occurrence of fascioliasis in the state of Espírito Santo, southeastern region of Brazil.

Oliveira et al. (2007) investigated about break of fascioliasis in the municipality of Canutama, state of Amazonas, northern region of Brazil, regarding the characteristics of occurrences of positive cases of $F$. hepatica and the related exposure factors. They did not observe any significant association with factors relating to water supply and proper sewage disposal. These associations were verified in the present study, even though the host species differed.

Concerning economic losses caused by condemnation of livers from cattle that presented Fasciola in the state of Goiás between the years 2007 and 2014, approximately R $\$ 15,072.75$ (US\$ 4,785) were lost. This amount was lower than what was found by Bernardo et al. (2011), who estimated losses of $\mathrm{R} \$ 649,187.50$ between the years 2006 and 2009 in an endemic region (south of the state of Espírito Santo). It is important to emphasize that the estimates for the state of Goiás may increase drastically if preventive measures to decrease dissemination of this parasitic disease are not implemented.

Based on the results obtained, it can be concluded that the average prevalence of $F$. hepatica among cattle in the Brazilian state of Goiás over the period analyzed was $0.0026 \%$ (95\% CI $=0.0024-0.0028)$. High odds ratio values were found for the northwestern and central mesoregions. The mesoregions diagnosed as presenting higher chances of findings of animals with fascioliasis, given that they had the largest effective bovine herd sizes $(\mathrm{P} \leq 0.05)$ were the northwestern region, southern region, part of the central region and two municipalities (Formosa and Flores de Goiás) in the eastern region. Between 2007 and 2014, the meat industry lost nearly
$\mathrm{R} \$ 15,072.75$ (US\$ 4,785) due to presence of adult F. hepatica in the livers of cattle in the state of Goiás.

The results observed in the present study emphasize the importance of undertaking strategic policy actions and measures, with specific antiparasitic treatments against fascioliasis among cattle in the northwestern, southern and central mesoregions, and in some municipalities in the eastern region, in an attempt to control dissemination of this important zoonosis in the state of Goiás. Additionally, new studies need to be conducted in these regions, focusing on identifying possible presence of intermediate hosts (mollusks) that might act as sources of infection with F. hepatica, both for cattle and for humans.

\section{References}

Aleixo MA, Freitas DF, Dutra LH, Malone J, Martins IVF, Molento MB. Fasciola hepatica: epidemiology, perspectives in the diagnostic and the use of geoprocessing systems for prevalence studies. Semina: Ciênc Agrár 2015; 36(3): 1451-1466. http://dx.doi.org/10.5433/1679$0359.2015 \mathrm{v} 36 \mathrm{n} 3 \mathrm{p} 1451$.

Alves DP. Distribuição e fatores associados à infecção por Fasciola hepatica em bovinos em municípios do sul do estado do Espirito Santo no periodo de 2008/2009 [tese]. Alegre: Universidade Federal do Espírito Santo; 2010

Araújo JLB, Linhares GFC, Oliveira APM, Amoril JG, Freitas MR, Costa ICC, et al. Infecçôes autóctones de bovinos por Fasciola hepatica Linnaeus, 1758 (Trematoda, Fasciolidae) no estado de Goiás, Brasil. Rev Patol Trop 2007; 36(1): 96-100. 
Araújo JLB, Linhares GFC, Paçô JM. Ocorrência de Lymnaea columella (Say, 1817) (Mollusca, Pulmonata, Lymnaeidae), no estado de goiás. Consideraçóes sobre os parasitos por ela transmitidos. Rev Patol Trop 1995; 24(2): 291-300.

Bennema SC, Scholte RGC, Molento MB, Medeiros C, Carvalho OS. Fasciola hepatica in bovines in Brazil: data availability and spatial distribution. Rev Inst Med Trop Sao Paulo 2014; 56(1): 35-41. http:// dx.doi.org/10.1590/S0036-46652014000100005. PMid:24553606.

Bernardo C, Carneiro MB, Avelar BR, Donatele DM, Martins IVF, Pereira MJS. Prevalence of liver condemnation due to bovine fascioliosis in Southern Espírito Santo: temporal distribution and economic losses. Rev Bras Parasitol Vet 2011; 20(1): 49-53. http://dx.doi.org/10.1590/ S1984-29612011000100010. PMid:21439232.

Brasil. Ministério da Agricultura, Pecuária e Abastecimento de Alimentos. Regulamento de inspeçâo industrial e sanitária de produtos de origem animal Gazeta Oficial, Brasília, maio 1952.

Centers for Disease Control and Prevention - CDC. Epi Info. [online]. Atlanta: CDC; 2015 [cited 2016 Jun 16]. Available from: https://search. cdc.gov/search/?query=regression+logistic\&utf8=\%E2\%9C\%93\&affili ate $=$ cdc-main

Ferreira MM, Revoredo TB, Ragazzi JP, Soares VE, Ferraldo AS, Mendonça RP, et al. Prevalência, distribuição espacial e fatores de risco para cisticercose bovina no estado de São Paulo. Pesq Vet Bras 2014; 34(12): 1181-1185. http://dx.doi.org/10.1590/S0100-736X2014001200006.

Freitas D, Martins IVF, Santos GMADA, Santos AR, Gomes D. Bioclimatic distribution and prevalence maps for Fasciola hepatica in Espírito Santo State, Brazil. J Venom Anim Toxins Incl Trop Dis 2014; 20(1): 32. http:// dx.doi.org/10.1186/1678-9199-20-32. PMid:25101121.

Google. Visualização dos Rios Crixas e Araguaia [online] 2017 [cited 2017 Jul 26]. Available from: https://www.google.com.br/search?q=imagem $+p$ elo+google + maps + do + rio + crixas\&source $=\operatorname{lnms} \&$ tbm $=$ isch\&sa $=X \& v e d$ $=0$ ahUKEwiZ3qOWxevZAhUIfpAKHdybC-MQ_AUIDCgD\&biw=1 093\&bih=470\#imgrc=tYcvZmwMPjfJ2M
Instituto Brasileiro de Geografia e Estatística - IBGE. Cidades [online]. 2016 [cited 2016 Jun 16]. Available from: http://cidades.ibge.gov.br/ xtras/uf.php?lang $=\&$ coduf $=52 \&$ search $=$ goias

Martins IV, Avelar BR, Bernardo C, Leão AC, Salim MJ. Distribution of bovine fascioliasis and associated factors in South Espírito Santo, Brasil: an update. Rev Bras Parasitol Vet 2014; 23(1): 23-29. http://dx.doi. org/10.1590/S1984-29612014003. PMid:24728357.

Martins IV, de Avelar BR, Pereira MJ, da Fonseca AH. Application of a geographical information system approach for risk analysis of fascioliasis in southern Espírito Santo State, Brazil. Geospat Health 2012; 6(3): S87-S93. http://dx.doi.org/10.4081/gh.2012.126. PMid:23032288.

Oliveira AA, Nascimento AS, Santos TAM, Carmo GMI, Dimech CPN, Alves RMS, et al. Estudo da prevalência e fatores associados à fasciolose no Município de Canutama, estado do Amazonas, Brasil. Epidemiol Serv Saude 2007; 16(4): 251-259.

Oliveira EL. Prevalência e fatores associados à distribuição da Fasciola hepatica Linnaeus, 1758 em bovinos dos municípios de Careaçú e Iatajubá, região da bacia do rio Sapucaí - Minas Gerais [dissertação]. Belo Horizonte: Universidade Federal de Minas Gerais; 2008.

Pereira NP, Rossi GAM, Lopes WDZ, Almeida HM, Mathias LA, Soares VE, et al. Spatial analysis of bovine cysticercosis in the state of Mato Grosso do Sul, Brazil — The needs of interventions in animal and human populations. Vet Parasitol Reg Stud Rep 2017; 8: 94-98.

Rossi GA, Simoni HA, Lopes WD, Almeida HM, Soares VE, Vidal AM, et al. Prevalence and geospatial distribution of bovine cysticercosis in the state of Mato Grosso, Brasil. Prev Vet Med 2016; 130: 94-98. http://dx.doi.org/10.1016/j.prevetmed.2016.06.008. PMid:27435651.

Suess RC, Carvalho H So. Mesorregião do Noroeste Goiano: uma abordagem holística e suas múltiplas determinaçōes. Soc Território 2014; 26(1): 122-138.

Yokananth S, Ghosh S, Gupta SC, Suresh MG, Saravanan D. Characterization of specific and cross-reacting antigens of Fasciola gigantica by immunoblotting. Parasitol Res 2005; 97(1): 41-48. http:// dx.doi.org/10.1007/s00436-005-1371-1. PMid:15952043. 